\title{
The origins of strengthening in nanostructured metals and alloys ${ }^{\left({ }^{\circ}\right.}$
}

\author{
D.G. Morris*
}

\begin{abstract}
Nanostructured metals and alloys have a variety of chemical and physical properties that are greatly modified by the nano-scale of their microstructure. At the same time, these materials generally show very high strength, although ductility or toughness may not be good. Strength increases as the microstructure scale reduces from the macro-micro level and even finer, but sometimes the strength appears to fall as the structure scale approaches the nano level. These strength variations are examined here, and the mechanisms responsible for both strengthening and weakening are discussed. The fall in ductility and toughness as materials become nanostructured is a complex topic that requires extensive analysis, but this will not be treated in the present overview.
\end{abstract}

Keywords Nanomaterials; Mechanical properties; Strength; Grain size; Hall-Petch strengthening.

\section{El origen del endurecimiento de metales y aleaciones nanoestructurados}

\begin{abstract}
Resumen
Los metales y aleaciones nanoestructuradas muestran una serie de propiedades químicas y físicas fuertemente modificadas cuando su microestructura entra en la escala nano. A la vez, estos materiales muestran generalmente alta resistencia pero mediocre ductilidad o tenacidad. La resistencia aumenta cuando baja la escala de la microestructura desde el nivel micro hacia el nivel nano, pero a veces la resistencia parece reducir por las microestructuras mas finas. Se examinan aquí todas estas variaciones y se discuten los mecanismos responsables del endurecimiento y ablandamiento. Los cambios de ductilidad o tenacidad cuando la microestructura entra en la escala nano necesitan un análisis detallado que no se trata en este articulo.
\end{abstract}

Palabras clave

\section{INTRODUCTION}

For materials with conventional, large grains, stress concentrations build up at grain boundaries during deformation, initiating deformation in neighbouring grains and then spreading through the entire material. This process leads to strengthening as the grain size reduces, and is described by the Hall-Petch relationship. The process continues down into the nano-regime. In some experimental studies the Hall-Petch strengthening continues to grains of only a few nanometres in size, while other studies report a saturation or loss of strengthening for grains smaller than tens or hundreds of nanometres. This loss of hardening has been termed the inverse HallPetch dependence. When examined closely, the strengthening loss is often seen to be a consequence of material imperfections. A variety of different deformation mechanisms can nevertheless operate as the grain size falls below several tens of nanometres, leading to changes in strengthening. These different deformation mechanisms will be considered, and their effect on strength discussed. Strengthening mechanisms operating as the grain size is reduced have been analysed in several previous reviews, e.g. ${ }^{[1-5]}$. The present overview attempts a simple synthesis of our understanding in this area, now that a general consensus of the important strengthening mechanisms is emerging.

In addition to strength in single phase (single element) materials, the role of solute additions and atomic ordering in nanomaterials will be considered, as well as the role of second phase particles, and interesting strength improvements shown possible. Such complex nanocrystalline alloys have not been examined in much detail, and deserve further

(•) Trabajo recibido el día 8 de febrero de 2010 y aceptado en su forma final el día 7 de abril de 2010.

*Department of Physical Metallurgy, CENIM-CSIC, Avda. Gregorio del Amo 8, 28040 Madrid, Spain. david.morris@cenim.csic.es 
attention. Nanostructured materials fabricated by severe plastic deformation contain a mixture of dislocations and tangles, as well as low angle and high angle grain boundaries, and each can contribute to overall strength.

\section{STRENGTH VARIATION WITH GRAIN SIZE IN CONVENTIONAL POLYCRYS - TALS - THE HALL-PETCH MODEL}

Refining grain size is one of the most important ways to increase strength, and is described by the well-known Hall-Petch equation:

$$
\sigma_{\mathbf{y}}=\sigma_{0}+\mathbf{k ~ d}^{-1 / 2}
$$

where $\sigma_{\mathrm{y}}$ is the yield stress, $\sigma_{0}$ a friction stress, $\mathrm{d}$ the grain size and $\mathrm{k}$ a constant. The strengthening effect depends on strain within one grain being blocked at a grain boundary, where a grain-size dependent dislocation pile-up and stress concentration forms which induces slip in a second grain. A smaller grain size implies a proportionally smaller pile-up, and therefore a smaller stress concentration to activate the new dislocation source. The extension of such Hall-Petch strengthening to the nanoscale has been reviewed on several occasions, for example ${ }^{[2-5]}$.

A typical example of the hardness variation with reciprocal square root of grain size for $\mathrm{Fe}$ is shown in figure $1^{[6-13]}$. Grain refinement here has generally been achieved by milling powders. The data are grouped into two linear regions, for coarse grains and very fine grains. The transition from coarse-grain Hall-Petch behaviour to fine-grain Hall-Petch behaviour corresponds approximately to the grain size where an internal dislocation substructure is no longer possible, and will be analysed later in the present section. This graph shows that the Hall-Petch representation of hardening may be extended from very coarse grains to the finest grains produced, about 5-6 $\mathrm{nm}$ in size. Within the nanoregime, however, the Hall-Petch slope $\mathrm{k}$ appears to be lower than that found for coarse grained materials.

A corresponding Hall-Petch representation for a wide range of $\mathrm{Cu}$ samples is shown in figure 2. Some of the materials represented here were prepared by plastic straining ${ }^{[14}$ and 15$]$, others by milling or by inert gas condensation techniques ${ }^{[16-19]}$, with most of the powder samples compacted to bulk material. A wide range of strengthening behaviour is observed, from a high value of Hall-Petch slope, similar to very coarse grains $^{[14 \text { and } 15]}$, a very low value of Hall-

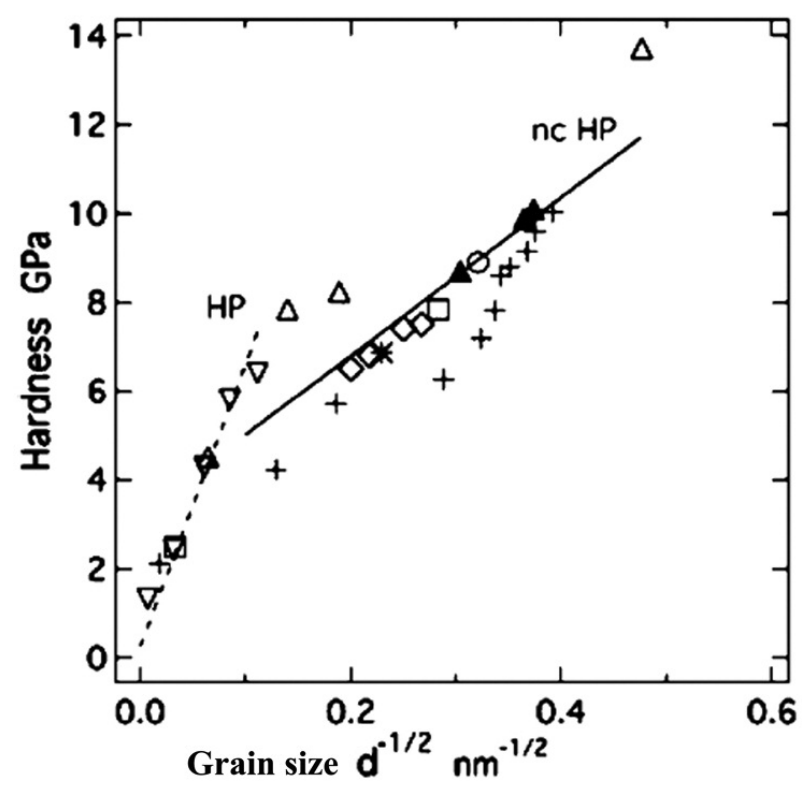

Figure 1. Variation of hardness of milled Fe with reciprocal square root of grain size, i.e. a Hall-Petch representation. Taken from Guduru et al. ${ }^{[13]}$, with source data indicated in the text. $\mathrm{HP}$ and ncHP refer to the two regions of classical (microcrystalline) and nanocrystalline grain size where two different Hall-Petch slopes are obtained. See text for description.

Figura 1.Variación de dureza de Fe molido con la raíz reciproca del tamaño de grano, i.e. una representación de tipo Hall-Petch. De Guduru et al. ${ }^{[13]}$. HP y ncHP se refieren a las dos regiones de tamaño de grano convencional (microcristalino) y nanocristalino donde se ven dos dependencias distintas de pendiente de Hall-Petch. Ver detalles en el texto.

Petch slope from coarse to fine grains ${ }^{[16,18}$ and 20$]$, a moderate Hall-Petch slope to some intermediate grain size followed by an absence of hardening ${ }^{[19}$ and 21-24], or a moderate Hall-Petch slope to an intermediate grain size but followed by notable softening for finer grains ${ }^{[17]}$. Similar results have been obtained in various other nanocrystalline materials ${ }^{[25-28]}$. This unusual saturation of strength or softening at very fine grain sizes can generally be related to imperfections of material processing, for example retained porosity after powder compaction, leading to lower hardness and compressive strength and especially reduced strength or premature failure: when tested in tension ${ }^{[18 \text { and } 19]}$.

The Hall-Petch model has been criticised for relying on rarely observed pile-up dislocation configurations to create stress concentrations and 
THE ORIGINS OF STRENGTHENING IN NANOSTRUCTURED METALS AND ALLOYS EL ORIGEN DEL ENDURECIMIENTO DE METALES Y ALEACIONES NANOESTRUCTURADOS

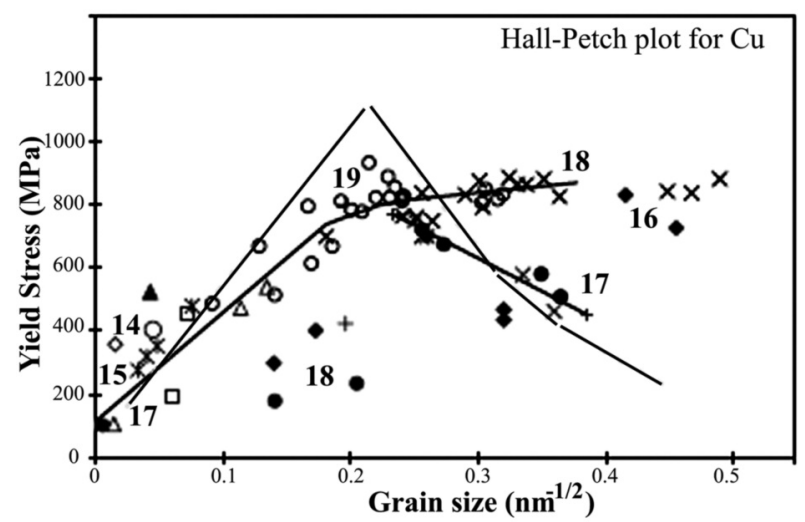

Figure 2. Variation of yield stress of Cu with reciprocal square root of grain size. Sources of data $^{[14-19]}$ are indicated. Figure is adapted from ${ }^{[4]}$. Note that the lines drawn are simple guides for the eye, illustrating the different families of strength variation found in various studies.

Figura 2. Variación de la tensión del límite elástico de Cu con el raíz reciproca del tamaño de grano. Se indican los origines ${ }^{[14-19]}$ de los datos. La figura ha sido adaptada desde ${ }^{[4]}$. Nota que las líneas sirven simplemente para guiar los ojos, e ilustran las diferentes familias de variación de resistencia observadas en distintas estudios.

considering that the fresh Frank-Read type source lies inside the new grain. $\mathrm{Li}^{[29]}$ proposed instead that grain boundary ledges acted as the sources for dislocations in the undeformed grain. This concept was subsequently modified ${ }^{[30}$ and 31$]$ by suggesting that geometrically necessary dislocations were created near grain boundaries where the deforming grain interior evolved to the undeforming grain boundary region. Meyers and Ashworth ${ }^{[32]}$ proposed a model, called the core-and-mantle model, which considered the polycrystalline material as a composite of hard grain boundary region and soft grain interior region. This model was based on the Ashby model of storage of geometrically necessary dislocations near grain boundaries ${ }^{[30}$ and 31$]$, and also on the experimental observation of higher densities of stored dislocations near boundaries and at triple points. The model has been extended ${ }^{[33]}$ to the nanoscale, where grain boundaries and triple points occupy a large fraction of the total volume. The low density of dislocations in grain interiors (core) allow easy dislocation glide and low work hardening, while the grain boundary regions (mantle) require extensive dislocation cutting and cross-slip, increasing both strength and work hardening rate. The composite material strength $\left(\sigma_{C}\right)$ can be described in terms of area fractions of grain interior
$\left(\mathrm{A}_{\mathrm{G}}\right)$ and boundary regions $\left(\mathrm{A}_{\mathrm{GB}}\right)$ and the strengths of these respective regions $\left(\sigma_{\mathrm{G}}\right.$ and $\left.\sigma_{\mathrm{GB}}\right)$ as:

$$
\sigma_{\mathbf{C}}=\mathbf{A}_{\mathbf{G}} \sigma_{\mathbf{G}}+\mathbf{A}_{\mathrm{GB}} \sigma_{\mathrm{GB}}
$$

The area fraction occupied by the hardened grain boundary region, including the triple point region, depends on the value of grain size relative to the thickness of the hardened region. Noting a relationship of the thickness of the hardened region to the grain size, the composite strength varies with grain size $(\mathrm{d})$ as:

$$
\sigma_{C}=\sigma_{G}+k_{1}\left(\sigma_{G B}-\sigma_{G}\right) d^{-1 / 2}-k_{2}\left(\sigma_{G B}-\sigma_{G}\right) d^{-1}
$$

For large grain sizes (near the micron) the reciprocal square root term in equation ( 3 ) dominates, and classical Hall-Petch dependence applies. For very fine grain sizes, the reciprocal grain size term becomes dominant, and material strength decreases. In an intermediate regime the apparent Hall-Petch slope falls steadily, as strengthening evolves from classical Hall-Petch behaviour towards strength saturation. This saturation and strength loss occurs at grain sizes of the order of several tens of nanometres.

Strengthening as grain size is reduced can thus be understood on the basis of classical dislocation theories, modified to take account of the large grain boundary area and the nearby hard regions as grain size falls to the nanolevel. The standard Hall-Petch dependency of yield strength applies for coarse grain sizes while, at grain sizes below about $100 \mathrm{~nm}$, the area fraction occupied by hard grain boundary regions becomes large and yield stress increases at a slower rate, eventually saturating and eventually falling.

\section{THE HALL-PETCH BREAKDOWN AT VERY FINE GRAIN SIZES}

The Hall-Petch or Meyers-Ashworth models explain that strength increases proportionally with the reciprocal square root of grain size as long as the grains are large enough to contain pile-ups or the hard-mantle/soft-core morphology. At very small grain sizes there may be insufficient space to allow an array of more than 1-2 dislocations, hardly a pile-up, or the core and hardened morphology. Hence some fine grain size limit to the Hall-Petch type relationship may be expected.

Very low dislocation densities are often found in nanocrystalline materials after deformation, and deformation may localise in intense shear bands ${ }^{4,28,}$ 34 and 35 ]. Deformation is associated with very low 
levels of work hardening, since no intense substructure forms. These observations appear inconsistent with the classical Hall-Petch model based on the formation of pile-ups and the core-and mantle model based on intensely deformed grain-boundary regions. Strain localisation into intense shear bands, and associated loss of work hardening, is generally observed for grains just smaller than the micron (the transition from homogeneous to inhomogeneous deformation occurs in the 1000-100 nm grain size range), although sometimes homogeneous flow is retained to much finer grains ${ }^{[28]}$. Such observations suggest that the homogeneous-heterogeneous strain distribution has no direct influence on the strengthening-grain size behaviour.

The grain size where dislocation arrays can no longer form has been examined on several occasions. Nieh and Wadworth ${ }^{[36]}$ considered the case where the elastic repulsion between the first and second dislocations of a nascent pile-up is greater than the material strength such that only single dislocations will be found. They suggested a critical grain size $\left(d_{c}\right)$, below which Hall-Petch strengthening is no longer possible, as:

$$
\mathbf{d}_{\mathrm{c}}=\mathbf{G} \mathbf{b} /\left\{(1-\mathrm{v}) \mathbf{H}_{\mathrm{v}}\right\}
$$

where $G$ is the shear modulus, $b$ the Burgers vector, $v$ the Poisson's ratio and $\mathrm{H}_{v}$ the material hardness. An analogous relationship has been deduced ${ }^{[37}$ and ${ }^{38]}$ by arguing that the Hall-Petch dependence would break down when the applied flow stress is high enough to bow single dislocations by a Frank-Read or Orowan type process, as:

$$
H_{v}=H_{v 0}+k\left(1 / 2 \pi \alpha_{c}\right) \cdot\left\{\ln \left(d / r_{0}\right)\right\} \cdot d^{-1 / 2}
$$

with $\mathrm{H}_{\mathrm{v}}$ the hardness of the material with grain size $\mathrm{d}, \mathrm{H}_{\mathrm{v} 0}$ the hardness of single crystal material, $\mathrm{k}$ the Hall-Petch slope, $\alpha_{c}$ is $1 / 2 \pi\left\{\ln \left(d_{\text {crit }} / r_{0}\right)\right\}$, with $d_{\text {crit }}$ the critical grain size where Hall-Petch dependence no longer applies, and $\mathrm{r}_{0}$ the dislocation core size. Yet another approach ${ }^{[39]}$ analyses the stress concentration at a pile-up in terms of the number of dislocation and the pile-up length, and shows that the Hall-Petch relationship can be expected down to pile-ups of about 2-3 dislocations, at which point the stress concentration becomes insufficient.

These expressions for the limiting grain size ${ }^{[36-38]}$ all lead to the conclusion that the Hall-Petch relationship can be respected for grain sizes down to about 5-10 $\mathrm{nm}$ for $\mathrm{Fe}, 10-20 \mathrm{~nm}$ for $\mathrm{Al}$ and $\mathrm{Cu}, 10-15$ $\mathrm{nm}$ for the ceramic $\mathrm{TiO}_{2}$, with possibly larger values for materials with complex dislocation core structures. This conclusion agrees with the data shown in figure 1 , with the Hall-Petch relationship respected for Fe down to very fine grain sizes. There is only partial agreement with the $\mathrm{Cu}$ data of figure 2, where grains larger than $20 \mathrm{~nm}$ generally show good grain-size hardening, but finer grains show great scatter and inconsistency of observed strength variations.

\section{HALL-PETCH BREAKDOWN AND THE IMPORTANCE OF DEFECTS IN THE NANOMATERIALS}

The data in figures 1 and 2 show that the strengthgrain size dependence may be described by the HallPetch relationship down to grain sizes of about $6 \mathrm{~nm}$ (for $\mathrm{Fe}$, figure 1 ) or show highly variable behaviour for grains smaller than 50-100 nm (for $\mathrm{Cu}$, figure 2). Classical dislocation theories suggest that this relationship could well be valid down to grains sizes of 5-20 nm. The next section discusses other deformation mechanisms that may operate in materials with such very fine grain sizes, while the present section considers imperfections in the nanocrystalline state that may be responsible for unusual and highly variable strength behaviour for grains smaller than about $100 \mathrm{~nm}$. The term defective materials here describes materials for which behaviour is dominated by processing inhomogeneities which are not intrinsic features of the nanocrystalline state.

Figure 3 shows three examples of results for $\mathrm{Ni}$ alloys where the Hall-Petch relationship is clearly not respected for grain sizes below $15 \mathrm{~nm}, 20-40 \mathrm{~nm}$, or $120 \mathrm{~nm}^{[5,28 \text { and } 40-41]}$. In such cases simultaneous changes to microstructure or chemistry can often be noted with changes to grain size. For the electrodeposited $\mathrm{Ni}$-Fe samples in figure 3 a), the change of grain size is associated with varying $\mathrm{Fe}$ content ${ }^{[40]}$. Nanocrystalline materials prepared by electrodeposition, figure $3 \mathrm{~b})^{[28]}$, often show major changes of composition as grain size changes, often of poorly soluble metal or metalloid elements such as C, $\mathrm{S}$ or W [28 and 42-44]. Such changes of composition, which may concentrate at grain boundaries or be associated with other microstructural changes, can lead to significant changes of mechanical behaviour, putting in doubt the analysis of grain size dependence. The final example in figure $3 \mathrm{c})^{[41]}$ relates to an initially glassy Ni-P alloy, crystallized to different grain sizes. In this case there may be a thin amorphous layer at grain boundaries for the finest grain sizes, and thus the true grain size dependence may be masked by other factors.

Many of the variable results found with regards strength of nanocrystalline materials (low Hall-Petch slope, apparent saturation of strength fine grain sizes, 
THE ORIGINS OF STRENGTHENING IN NANOSTRUCTURED METALS AND ALLOYS EL ORIGEN DEL ENDURECIMIENTO DE METALES Y ALEACIONES NANOESTRUCTURADOS

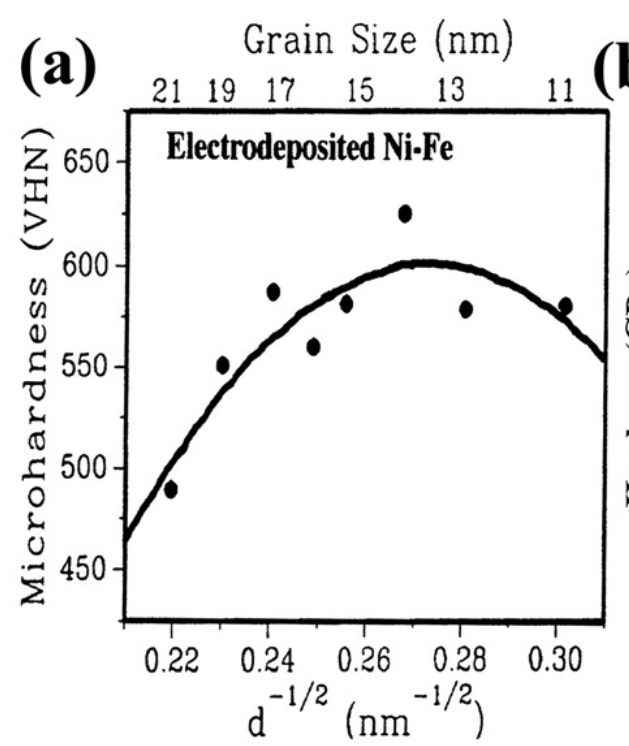

(b)
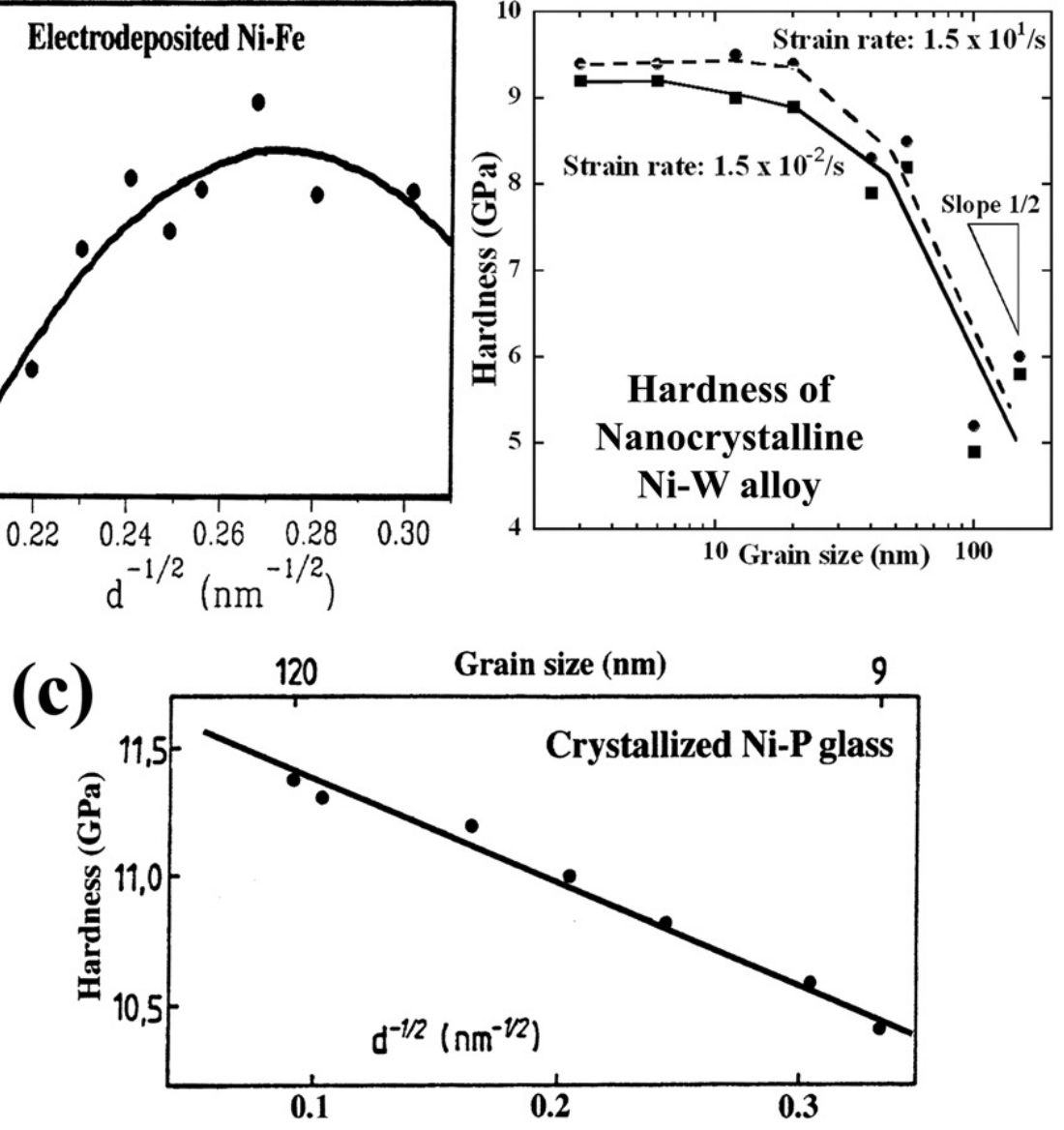

Figure 3. Variation of hardness with grain size for nanocrystalline Ni-base samples, where anomalous, non-Hall-Petch dependence is observed for fine grain sizes. Data from (a) Cheung et al. ${ }^{[40] ; ~(b) ~ T r e l e w i c z ~ a n d ~ S c h u h ~}{ }^{[28]}$; and (c) Lu et al. ${ }^{[41] .}$

Figura 3. Variación de dureza con el tamaño de grano de probetas de Ni nanocristalino, donde se observa una dependencia anómala para granos muy finos. Los datos son de (a) Cheung et al. [40]; (b) Trelewicz and Schuh ${ }^{[28]}$; and (c) Lu et al. ${ }^{[41]}$.

inverse Hall-Petch slope) -illustrated in figure 2were obtained when studying inert-gas condensed powders subsequently compacted to solid form [16 and 22]. These materials are highly flaw sensitive ${ }^{[20,22,24}$ and ${ }^{45}$, and defects remaining after processing, especially retained porosity and gaseous impurities, can greatly reduce strength and ductility ${ }^{[19}$ and 26$]$. There may be a significant retained gas content, presumably at grain boundaries, which can cause significant changes in mechanical behaviour. There is considerable doubt as to whether the observation of anomalous strengthening behaviour (strength saturation or inverse Hall-Petch dependency) is really due to the grain size variation, or may be associated with significant amounts of retained porosity and gases, or changes in the quality of grain-grain bonding.

\section{ALTERNATIVE DEFORMATION MECHANISMS AT VERY FINE GRAIN SIZES}

It is possible to extend classical dislocation theories for grain boundary hardening to grain sizes of the order of $5-30 \mathrm{~nm}$, but thereafter it is uncertain whether these models are valid. There are two possible scenarios for changes of mechanism: (i) that well-known deformation mechanisms for coarsegrained materials may be activated by especially fine grain sizes, or (ii) that new mechanisms may appear at very fine grain sizes since very high stresses are required for conventional dislocation mechanisms. These two aspects are covered here. First, we consider classical deformation mechanisms found in normal 
polycrystalline materials that may be activated, and then analyse their importance in various studies. Secondly, we present some new mechanisms, analysing their applicability to nanocrystalline materials.

\subsection{Classical deformation mechanisms activated by fine grain sizes}

Deformation mechanisms often found in conventional polycrystalline metals at elevated temperatures include diffusional creep and grain boundary sliding ${ }^{[4,5}$ y 42$]$. These may be activated at room temperature in materials with nanocrystalline grains since the deformation rate increases rapidly as grain size decreases.

Two diffusional creep mechanisms may be considered, namely Nabarro-Herring creep ${ }^{[46}$ and 47$]$, equation (6), and Coble creep ${ }^{[48]}$, equation (7). The stronger grain size dependence of Coble creep means that this mechanism is more likely at nanograin sizes.

$$
\begin{gathered}
\dot{\varepsilon}=\frac{14 \Omega \sigma D_{1}}{k T d^{2}} \\
\dot{\varepsilon}=\frac{14 \pi \Omega \sigma \delta D_{g b}}{k T d^{3}}
\end{gathered}
$$

Here $\dot{\varepsilon}$ is the creep rate under applied stress $\sigma$ in material of grain size d. $\Omega$ is the atomic volume, $\mathrm{k}$ the Boltzmann constant, $\mathrm{T}$ the absolute temperature. $\mathrm{D}_{1}$ is the lattice diffusivity, $\mathrm{D}_{\mathrm{gb}}$ the grain boundary diffusivity and $\delta$ the grain boundary thickness. These processes are characterised by a creep rate linearly dependent on stress and on the reciprocal square or reciprocal cube of grain size.

Sliding at grain boundaries may instead control deformation ${ }^{[49]}$ with lattice diffusion (Eq. (8)) or grain boundary diffusion (Eq. (9)) controlling creep, as:

$$
\begin{aligned}
& \dot{\varepsilon}=8 \times 10^{6} D_{1}\left(\frac{G b}{k T}\right)\left(\frac{b}{d}\right)^{2}\left(\frac{\sigma}{G}\right)^{2} \\
& \dot{\varepsilon}=2 \times 10^{5} D_{g b}\left(\frac{G b}{k T}\right)\left(\frac{b}{d}\right)^{3}\left(\frac{\sigma}{G}\right)^{2}
\end{aligned}
$$

Here, $G$ is the shear modulus and $b$ the Burgers vector, with other parameters having the same meaning as in equations (6) and (7). Creep now depends on the square of applied stress and again reciprocal square or reciprocal cube of grain size. An examination of the dependence of creep rate on applied stress, grain size, and temperature thus allows the determination of the operating deformation mechanism.

\subsection{Analysis of deformation of inert- gas-condensed compacted-powder materials}

Section 4 examined strength saturation or loss in inert-gas condensed and compacted nanocrystalline materials at very fine grain sizes in terms of the importance of flaws due to imperfect fabrication. Can this strength saturation or loss instead be caused by the onset of diffusional or sliding mechanisms requiring lower stresses than expected by extrapolation of the Hall-Petch dependency?

It has been suggested that the strength saturation or fall at the finest grain sizes may be due to the

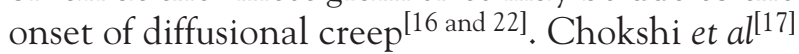
analysed softening in $\mathrm{Cu}$ and $\mathrm{Pd}$ at grain sizes below $15-20 \mathrm{~nm}$ in terms of Coble creep and found qualitative agreement. A later study of the temperature dependence of hardness of nanocrystalline copper ${ }^{[23]}$, however, found hardness variations which could not be explained by creep mechanisms. Creep studies sometimes found linear creep $^{[20]}$ but with creep rate much slower than expected for Coble creep. Other studies ${ }^{[18}$ and 50$]$ found creep rates varying with time and decreasing steadily. Yet other studies have found creep rates very much slower than predicted by these creep mechanisms. In summary, the experimental data are inconclusive and unconvincing that diffusional or sliding creep mechanisms operate in these nanocrystalline materials at room temperature.

\subsection{Analysis of deformation of other nanocrystalline materials}

Creep-like behaviour has been observed in nanocrystalline materials prepared both by crystallization of metallic glasses and by electrodeposition. Crystallized Ni-P and Fe-B-Si alloys ${ }^{[51}$ and 52$]$ show much faster deformation at nanocrystalline grain sizes than at micron grain sizes. Creep appears to be generally consistent, but 
not completely, with the operation of Coble creep. Significant creep strain during a primary stage ${ }^{[52]}$, however, suggests other deformation mechanisms also take place. Deformation mechanisms occurring are complicated and not completely understood.

Room temperature creep of electrodeposited nanocrystalline metals has been examined on several

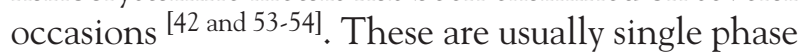
metals (e.g. $\mathrm{Cu}, \mathrm{Ni}$ ) containing impurities necessary for obtaining the nanostructure. Wang et al. ${ }^{[42]}$ examined creep in nanocrystalline nickel and found that the Hall-Petch relationship described strength down to grain sizes near $25-40 \mathrm{~nm}$, but thereafter softening occurred. Grain boundary sliding was deduced to control deformation for grain sizes of 20-40 nm, with dislocation creep becoming important at high applied stresses. Higher creep rates in material with $6 \mathrm{~nm}$ grain size were explained by diffusional (i.e. Coble) creep. The processes taking place during creep are, however, more complicated than this simple description implies. The creep rate, for example, was observed to vary with time under load, with significant initial transients in strain and strain rate noted. Another study ${ }^{[53]}$ of creep of electrodeposited $\mathrm{Ni}$ again found significant primary creep before the onset of a steady stage regime controlled by Coble creep. Creep deformation in electrodeposited $\mathrm{Cu}$ with grain size of $30 \mathrm{~nm}$ has also been examined ${ }^{[54]}$. Here, primary creep was found initially, and subsequent linear deformation appeared to be controlled by Coble creep. The processes occurring are more complex than this, however, and are not completely understood.

In summary, several studies have shown Coble creep-like behaviour, or sometimes grain boundary sliding, in nanocrystalline materials. It is, however, difficult to explain all aspects of deformation: a primary creep stage and subsequent creep rate falling logarithmically, perhaps never becoming truly steadystate; very significant internal or friction stresses opposing strain accumulation. It is still not clear whether deformation is indeed produced by diffusional or sliding mechanisms, whether such deformation is modified by the special nature of the grain boundaries, or whether other, new deformation mechanisms are operating.

\subsection{New experimental analysis of mechanical behaviour}

A better understanding of deformation in nanocrystalline materials has been obtained by analysing deformation as a thermally activated process, determining parameters such as activation energy $(\Delta \mathrm{G}$ or $\Delta \mathrm{F})$ and activation volume $(\Delta \mathrm{V})$. These analyses are presented here and the importance for suggesting new deformation mechanisms then considered.

Treating deformation as a thermally activated process $^{[3,4}$ and 55$]$, strain rate $\dot{\gamma}$ is written:

$$
\dot{\gamma}=\dot{\gamma}_{0} \exp \left[\frac{-\Delta \mathrm{G}\left(\mathrm{T}_{\text {eff }}^{*}\right)}{\mathrm{kT}}\right]=\dot{\gamma}_{0} \exp -\left[\frac{\Delta \mathrm{F}-\mathrm{T}_{\text {eff }}^{*} \Delta \mathrm{V}^{*}}{\mathrm{kT}}\right]
$$

where $\dot{\gamma}$ is a constant, $\Delta \mathrm{G}\left(\tau_{\text {eff }}^{*}\right)$ the Gibbs free energy of activation of the stress-dependent controlling process, $\mathrm{k}$ the Boltzmann constant, $\mathrm{T}$ the absolute temperature, $\Delta \mathrm{F}$ the Helmholtz free energy (activation energy) and $\Delta \mathrm{V}^{*}$ the effective activation volume. $\tau_{\text {eff }}^{*}$ is the effective shear stress, with $\tau_{\text {eff }}^{*}=$ $\tau_{\text {appl }}-\tau_{\mu}$, and $\tau_{\text {appl }}$ the applied shear stress and $\tau_{\mu}$ the athermal contribution to flow stress, i.e. longrange internal stresses opposing flow. Shear stress and strain may be related to applied stress and strain by $\tau=\sigma / \sqrt{ } 3$ and $\gamma=\sqrt{ } 3 \varepsilon$, or $\dot{\gamma}=\sqrt{ } 3 \dot{\varepsilon}$.

Activation energy can be determined by studying changes in strain rate as the temperature changes at constant effective stress. Activation volume can be determined from changes in strain rate as the effective stress changes, at constant temperature. This can be achieved by jumping the strain rate, giving:

$$
\Delta V=\frac{\sqrt{3} k T \cdot \ln \left(\dot{\varepsilon}_{2} / \dot{\varepsilon}_{1}\right)}{\Delta \sigma}
$$

with $\Delta \mathrm{V}$ the apparent activation volume and $\Delta \sigma$ the change in applied stress as the strain rate jumps from $\dot{\varepsilon}_{1}$ to $\dot{\varepsilon}_{2}$, or examining stress relaxation at constant total strain, as:

$$
\Delta \tau=\frac{k T \cdot \ln (1+t / C)}{\Delta V}
$$

Here $\Delta \tau$ is the stress fall as a function of relaxation time $\mathrm{t}$, and $\mathrm{C}$ a constant.

Analysis of activation energy and volume leads to a good idea of which is the controlling deformation mechanism. Several measurements of activation volume have been reported ${ }^{[2,3}$ and 55$]$. Diffusional mechanisms are characterised by activation volumes of about the atomic volume (or $b^{3}$, where $b$ is the Burgers vector), with similar values presumably expected for grain boundary sliding. Dislocation movement in normal polycrystalline materials is 
characterised by activation volumes of the order of $1000 \mathrm{~b}^{3}$ (where a long dislocation segment moves forward by a few Burgers vectors to cut through a forest dislocation). Studies of activation volume in nanocrystalline materials show intermediate values for $\Delta \mathrm{V}$, of the order of $10-100 \mathrm{~b}^{3}$, illustrated in figure $4^{[3]}$. The apparent activation volume in $\mathrm{Cu}$ and $\mathrm{Ni}$ is seen to decrease as the grain size decreases from about $1000 \mathrm{~b}^{3}$, typical of dislocation movement through a forest, to about $10 \mathrm{~b}^{3}$ for the smallest grains. Similar values are reported for other nanocrystalline $\mathrm{fcc}$ materials. The small values of activation volume in nanocrystalline fcc materials indicate that neither conventional dislocation segments passing through dislocation forests nor diffusional creep processes control plastic deformation in these metals.

\subsection{Suggestions for new deformation mechanisms in nanocrystalline metals}

From the analysis of strain rate sensitivity of flow stress, and also with insight from molecular dynamics modelling of deformation, as well as detailed examinations of dislocations by transmission electron microscopy, a new consensus of deformation in

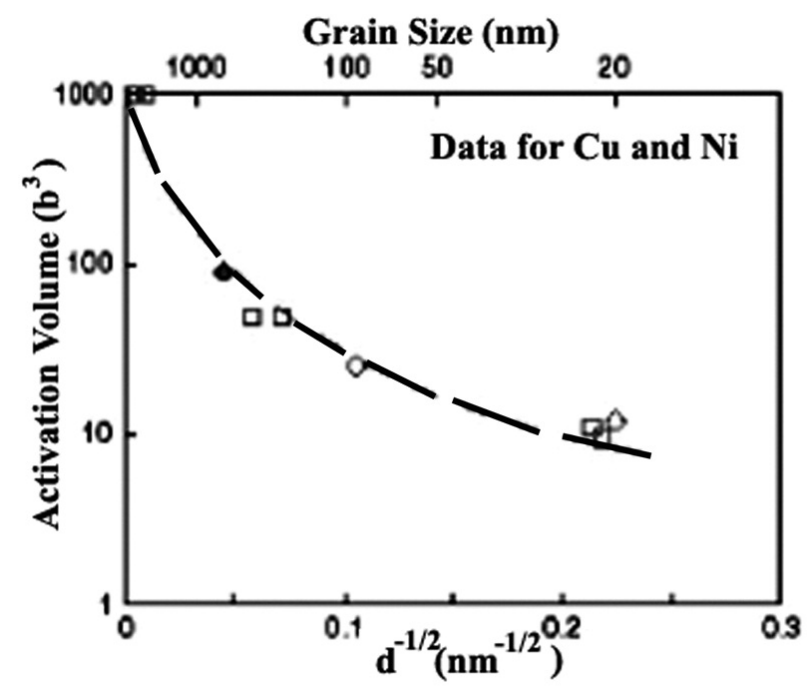

Figure 4. Values of activation volume in $\mathrm{Cu}$ and $\mathrm{Ni}$ over a wide range of grain sizes, from the micron level to the nano-scale. Data taken from Dao et al. ${ }^{[3]}$.

Figura 4. Valores del volumen de activación para Cu y Ni para un rango ancho de tamaño de grano, desde el nivel de la micra hasta el nivel nano. Los datos son de Dao et al. ${ }^{[3]}$. nanocrystalline metals, with grain size well below $50 \mathrm{~nm}$, is emerging ${ }^{[3,4}$ and 55$]$.

Work hardening is known to be low in nanocrystalline metals ${ }^{[5]}$ (at least following any rounded yield behaviour where flow stress may increase rapidly as the transition from elastic flow to plastic flow occurs), and is related to the very limited build-up of dislocation density and no dislocation substructure. A more common observation is the nucleation of individual dislocations at grain boundaries, which cross the grain to disappear at the opposite grain boundary ${ }^{[56}$ and 57]. The dislocations emitted may be perfect dislocations, or imperfect dislocations that trail stacking faults or lead to twins. This appearance of dislocations, and subsequent disappearance, is consistent with studies showing broadening of diffraction peaks during, but not after, deformation ${ }^{[58]}$.

Deformation controlled by the emission of single dislocations is consistent with small activation volumes, which can be described as $\Delta \mathrm{V}=\beta . \mathrm{d} . \mathrm{b} . \mathrm{b}$, where $d$ is the grain size, $b$ the Burgers vector, and $\beta$ a geometrical factor of. Activation volume thus falls with grain size, to tens of $b^{3}$ for grain sizes of $20 \mathrm{~nm}$, as in figure 4 . The measured activation volumes thus agree well with the model of single dislocation emission ${ }^{[2,3,55}$ and 59].

Noting that the applied stress must supply an energy $1 / 2 \mathrm{~Gb}^{2} .1$ ( $\mathrm{G}$ is the shear modulus, $b$ the Burgers vector and 1 the length of the new dislocation segment), it is clear that stress requirements can be greatly reduced when partial, Shockley dislocations are emitted, with energy reduced to $1 / 6 \mathrm{~Gb}^{2}$.1. This explains the activation of imperfect dislocation sources at very fine grain sizes, creating stacking faults or twins ${ }^{[2,57}$ and 59]. The transition to such partial dislocations is a mechanism of softening, since sources operate at stresses below that required for the equivalent perfect dislocation source.

Finally, molecular dynamics simulation of deformation in nanocrystalline materials ${ }^{[60}$ and 61$]$ is consistent in showing a transition from emission of perfect dislocations at boundary sources to partial dislocations at very fine grain sizes ${ }^{[62]}$. Atomic shuffling is also seen at grain boundaries, somewhat similar to sliding. These simulations also show easier deformation, at lower flow stresses, for grain sizes below 10-15 $\mathrm{nm}^{\text {[63 and 64]. }}$

Mechanical property analysis, transmission electron microscope investigations, and molecular dynamics simulation are consistent in seeing an evolution of deformation mechanism as grain size reduces. For grain sizes above $50 \mathrm{~nm}$, conventional dislocation behaviour controls, with stress concentrations leading to deformation propagation 
from grain to grain. For grain sizes of $20-50 \mathrm{~nm}$, a transition to single dislocation emission from grain boundaries occurs. For grains of $10-20 \mathrm{~nm}$, the dislocations become partials trailing stacking faults and twin faults. Below $10 \mathrm{~nm}$, grain boundary dislocations, atomic shuffles, and grain rotations become important, with flow stresses falling.

\section{OTHER FACTORS AFFECTING STRENGTH OF NANOSTRUCTURED MATERIALS}

The previous sections of this overview have considered mechanisms determining the strength of nanostructured grains, which are implicitly considered to be single phase (single element). The present sections consider the role played by other microstructural or alloying features which can be important in determining the deformation behaviour and strength of nanostructured materials, considering in turn the role of nanosize second phase particles within the nanograins, or at their boundaries; the role of solution additions or atomic ordering of the solution; and the strengthening expected when the boundaries are special - as twin boundaries or as low-angle grain boundaries - as well as the role of deliberately introduced dislocations.

\subsection{Strengthening caused by second phase particles}

Second phase particles contribute to strengthening when the particles are much finer than the grain size and distributed both within grains and at grain boundaries. For significant strengthening the particles must be large enough not to be easily cut, such that the Orowan mechanism operates. When the grain size is very small, these fine particles have sizes similar to the grain size, and it may be better to consider the material as a composite mixture of matrix grains and particles.

Orowan hardening by fine particles, size $\sigma$, present in volume fraction $f$ in a material of grain size $d>>$ $\phi$, can be described as:

$$
\sigma_{\mathrm{OR}}=\frac{\mathrm{m} 2 \mathrm{~Gb}}{1.18 \times 4 \pi(\lambda-\varphi)} \ln \left(\frac{\varphi}{2 \mathrm{~b}}\right)
$$

where $\mathrm{m}$ is the Taylor factor, $\mathrm{G}$ the shear modulus, $\mathrm{b}$ the Burgers vector and $\lambda$ the separation of particles on the shear plane ${ }^{[65]}$. Since particles tend to pin grain boundaries, grain size and particle size are often related, for example by the Zener relation, $d=0.66 \phi / \sqrt{ } f$, grain size and particle separation may be related:

$$
\mathbf{d} / \boldsymbol{\lambda}=\mathbf{0 . 6 6} / \sqrt{\mathbf{f}}
$$

Orowan strengthening models can clearly only be used for materials with a small volume fraction of second phase, say less than $10 \%$, but are independent of grain size.

Figure 5 shows an analysis of strengthening in copper alloys containing second phase particles ${ }^{[65]}$, where strength is related to the Orowan mechanism. A good description of the particle strengthening, i.e. $\sigma_{\mathrm{OR}}$ proportional to $\{1 /(\lambda-\phi) \cdot \ln (\phi / 2 b)\}$, is seen down to particle sizes of $7 \mathrm{~nm}$. Since particle size can be related to grain size, strengthening may be re-expressed in terms of grain size, (Eq. (1)), $\sigma_{\mathrm{y}}=\sigma_{0}+\mathrm{k} \mathrm{d}^{-1 / 2}$ ) with relatively good agreement found. The numerical value of the Hall-Petch slope, $k$, is $0.28 \mathrm{MPa} \sqrt{\mathrm{m}}$, however, greater than accepted values for $\mathrm{Cu}$ [66 and 67]. The analysis suggests that the major strengthening is due to particles with grain boundary strengthening being less important. The slower strengthening observed in figure 5 as the second phase particles refine to very fine sizes may be due to particles shearing or an inhomogeneous particle distribution as particles are trapped at grain boundaries.

Hardness in nanocrystalline FeAl has also been related to grain size, figure 6, ${ }^{68}$ and 69$]$ with exactly the same Hall-Petch slope as for Fe (Fig. 1). These

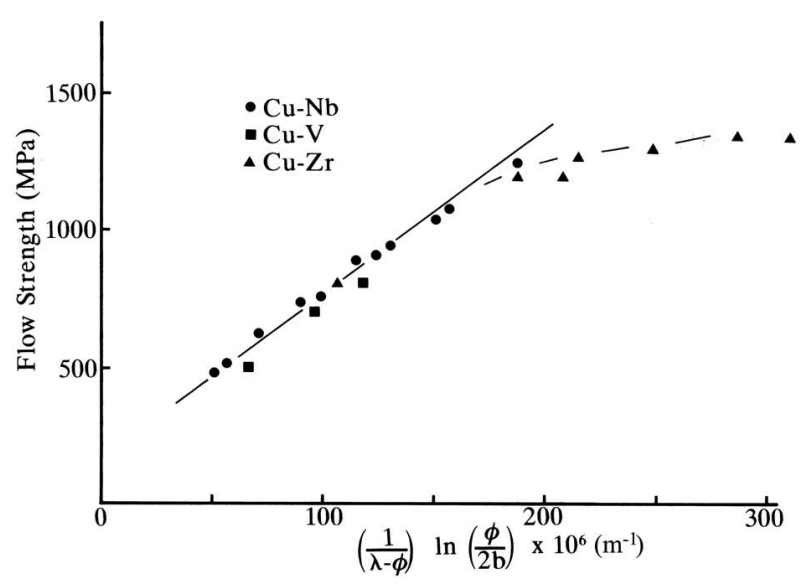

Figure 5. Analysis of strengthening in $\mathrm{Cu}-\mathrm{bcc}$ particle materials in terms of the Orowan strengthening model, from Morris and Morris ${ }^{[65]}$.

Figura 5. Análisis del endurecimiento de materiales compuestos Cu-partícula cc en relación con el modelo de Orowan, de Morris and Morris ${ }^{[65]}$. 


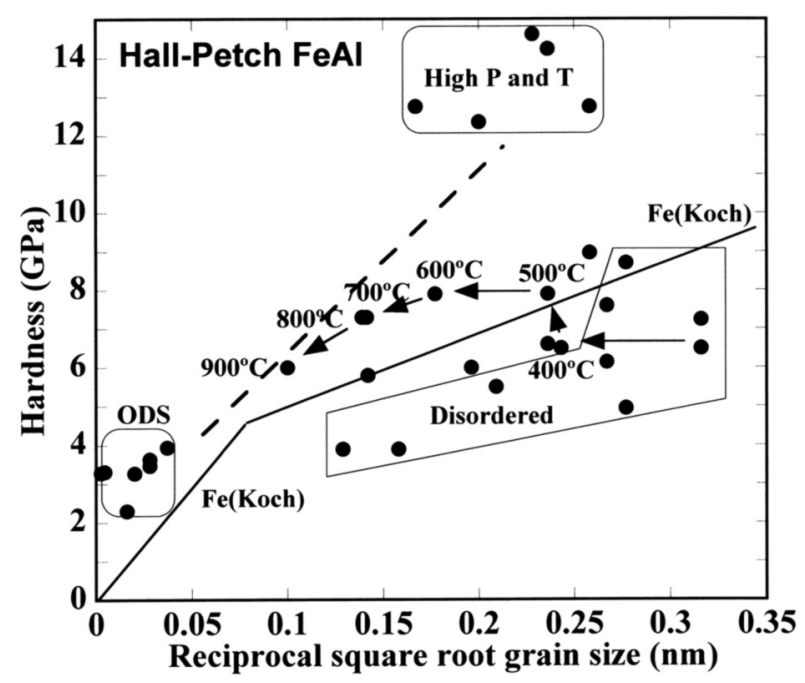

Figure 6. Hardness of $\mathrm{FeAl}$ related to grain size by the Hall-Petch relationship. Data points connected by arrows indicate hardness evolution on ageing, as oxide precipitates form ${ }^{[69]}$. Highest hardness is achieved after high pressure, high temperature consolidation of FeAl-TiC composites $^{[70]}$.

Figura 6. Dureza de FeAl relacionada con el tamaño de grano por la relación de Hall-Petch. Los datos se conectan por flechas que indican la evolución de dureza durante el recocido, cuando de forman precipitados de óxidos ${ }^{[69]}$. Las durezas más altas se obtienen después de consolidación de compuestos FeAl-TiC bajo condiciones de alta presión y alta temperatura[70].

materials also contained fine $\mathrm{Al}_{2} \mathrm{O}_{3}$ particles which are sufficiently fine that dislocations propagate with little difficulty. Particle coarsening on heat treatment led to initial strengthening, before softening as particle and grain coarsening occurred, as indicated by the sequence of arrows in figure 6 . Even greater hardening has been achieved by adding $30 \% \mathrm{TiC}$ to the intermetallic, as indicated by the high-pressure data in figure $6^{[70]}$. These materials have fine grain size, 20-30 nm, but both FeAl and $\mathrm{TiC}$ have similar size and the material should be considered as a composite with mixed grains of these two phases.

When second phase particles occupy a large volume fraction $(>10 \%)$ and particles are of similar or larger size than matrix grains, it is better to consider the material as a composite, using the rule of mixtures to describe strength. $\mathrm{He}$ and $\mathrm{Ma}{ }^{[71]}$ examined $\mathrm{Cu}-\mathrm{Fe}$ composites, with Fe fractions of 15-90 \%, with both phases of size $25-45 \mathrm{~nm}$, to find hardness levels much greater than expected, and argued that bcc-fcc interphase boundaries are much stronger than grain boundaries in single phase $\mathrm{Cu}$ and $\mathrm{Fe}$.

Guduru et al. ${ }^{[13]}$ mixed $\mathrm{Fe}$ with $\mathrm{Al}_{2} \mathrm{O}_{3}$, both of size about $10-50 \mathrm{~nm}$, and analysed hardness in terms of the rule of mixtures. The experimental hardness was much greater than predicted by the rule of mixtures, see figure 7, and it was argued that the much harder $\mathrm{Al}_{2} \mathrm{O}_{3}$ particles created a local heavily-work-hardened zone in the neighbouring Fe grains due to the large number of geometrically necessary dislocations formed during deformation.

\subsection{Strengthening caused by solute, order, and twin boundaries}

Only few studies examine the role of solute or order on the strength of nanocrystalline materials. Guduru et al. ${ }^{[13]}$ examined $\mathrm{Fe}-\mathrm{Pb}$ mixtures which had been milled to dissolve the $\mathrm{Pb}$. Figure 7 shows the evolution of hardness with $\mathrm{Pb}$ addition, with a large increase observed with $5 \% \mathrm{~Pb}$ addition. Examining expected hardening by the large $\mathrm{Pb}$ atoms in the Fe matrix according to the Fleischer solution hardening model ${ }^{[72]}$ showed, however, that hardening should be even greater. The authors speculated that the $\mathrm{Pb}$ atoms were not uniformly distributed in solution with some

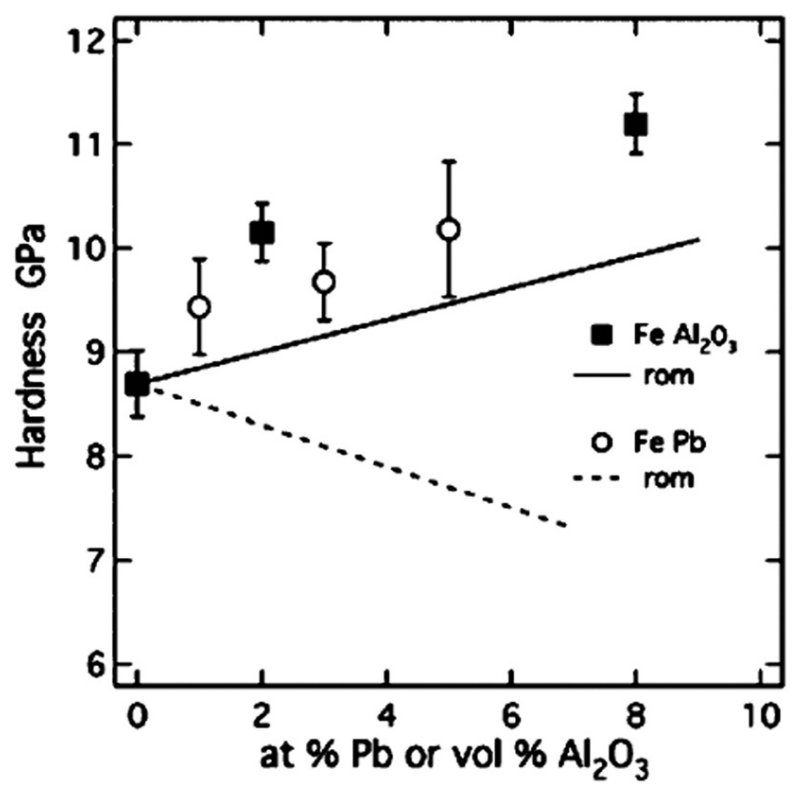

Figure 7. Hardness of Fe milled with $\mathrm{Al}_{2} \mathrm{O}_{3}$ and with $\mathrm{Pb}$, indicating that the data do not fit to the composite rule of mixtures ${ }^{[13]}$.

Figura 7. Dureza de Fe molido con $\mathrm{Al}_{2} \mathrm{O}_{3}$ y con $\mathrm{Pb}$, donde se demuestra que los datos no se conforme con la regla de mezclas ${ }^{[13]}$. 
$\mathrm{Pb}$ segregated at grain boundaries or as sub-nanometric clusters.

Nano intermetallic materials prepared by milling are often disordered ${ }^{[73]}$, which may affect mechanical behaviour. Nano-FeAl re-orders when annealed at $150-250^{\circ} \mathrm{C}[68,69$ and 73$]$ but there is no noticeable hardness change, as seen in figure 6 by the arrows indicating hardness evolution ${ }^{[69]}$. The super-partial dislocation separation is so large in this and many intermetallics, similar to the nanocrystalline grain size, that deformation can still be carried by the partial dislocations that characterise the disordered matrix.

As a final point, while the theoretical models (Hall-Petch/Core-and-Mantle/Molecular Dynamics) do not explain the role of solute on hardening, the evolution from a perfect dislocation source to a partial dislocation or twinning dislocation source is obviously easier when alloying reduces stacking fault energy.

Improved strength is also found when many twins are present, as may be introduced in materials of low stacking fault energy by electrodeposition ${ }^{[74]}$ or by rapid straining at low temperatures ${ }^{[75}$ and 76$]$. Twins can lead to strengthening independently of the grain size with strengthening determined by twin spacing instead of grain boundary spacing ${ }^{[74]}$. Such twin strengthening seems to be of great interest since it appears that ductility or toughness can remain high as strengthening is achieved ${ }^{[76}$ and 77$]$. Twins act as barriers to dislocation slip in the parent grain, in much the same way as grain boundaries, requiring new slip activation in the twinned region or the parent-oriented region found behind a subsequent twin boundary. Strengthening can then be described by the same formulation as for grain boundaries, such as the Hall-Petch approach. An alternative approach considers the nano-thick twinned regions, as determined by the close spacing of the pairs of bounding parent-twin interfaces, to be hard regions of a composite, with the overall strength given by a composite model of mixed hard and soft regions ${ }^{[76]}$. Coherent twin boundaries appear, however, to be able to spread stress concentrations more than grain boundaries, and hence are not easy sites for crack or cavity nucleation. This ability to suffer plastic deformation and store dislocations means that twin-strengthened materials show work hardening ${ }^{[76}$ and 77$]$, which may explain the improved ductility of these materials.

\subsection{Strengthening in materials with ultrafine microstructure prepared by severe plastic deformation}

Severe plastic deformation can lead to microstructural refinement and significant strengthening ${ }^{[78}$ and 79$]$.
Submicron or nano structures can be achieved after imposing very high strains (between 10 and 100) in materials where recovery is slow or where multiple phase components impose strong microstructural refinement.

At moderate strain levels (2-8), however, the microstructure is composed of random dislocations within dislocation cell walls or low angle grain boundaries (LAGB), contained within a smaller density of grain boundaries, or high angle grain boundaries (HAGB). For example: strains of 1-2 in $\mathrm{Al}$ or $\mathrm{Cu}$ lead to elongated dislocation cells; strains of 4 produce more-equiaxed dislocation cell/subgrains; strains of 10 produce microstructures of scale about $100-500 \mathrm{~nm}$, where $50-70 \%$ of the boundaries have misorientations above $15^{\circ}$, i.e. are defined as HAGB [78 and 79]. Similar dislocation cell structures of size about $250-75 \mathrm{~nm}$, respectively, have been found ${ }^{[80]}$ in $\mathrm{Al}$ and $\mathrm{Al}-\mathrm{Mg}$ alloy after straining to 2-8, with dislocation densities of $2 \times 10^{14}-2 \times 10^{15} / \mathrm{m}^{2}$, respectively. Similar structures are obtained in $\mathrm{Fe}$

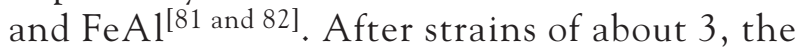
microstructure shows many randomly arranged dislocations inside a dislocation cell structure of size $200 \mathrm{~nm}$ with average boundary misorientation of $10^{\circ}$ and $15 \%$ of boundaries being HAGB. Dislocation cell structures are obtained for strains below 10, and nanocrystalline structures after straining above 100 .

Various explanations of strengthening by severe plastic deformation have been proposed. Valiev et $\mathrm{Al} .{ }^{[81]}$ argued that strengthening was caused by the many grain boundaries, i.e. by Hall-Petch strengthening. Gubizca et al. ${ }^{[80]}$, however, related strength $\left(\Delta \sigma_{\rho}\right)$, to the measured dislocation density $\left(\rho_{\text {loose }}\right)$ through the Taylor equation:

$$
\Delta \sigma_{\rho}=M \alpha G b \sqrt{\rho_{\text {loose }}}
$$

$\alpha$ is about $0.3, M$ the Taylor factor, $G$ the shear modulus, and $\mathrm{b}$ the Burgers vector. Leseur et al. ${ }^{[83]}$, on the other hand, suggested a Hall-Petch dependence of hardening for grains larger than 1 $\mu \mathrm{m}$, but a subgrain size dependence, i.e. $\Delta \mathrm{H}$ proportional to reciprocal subgrain size, for cells or subgrains smaller than $1 \mu \mathrm{m}$.

Hansen ${ }^{[66}$ and 67$]$ shows that dislocation cell boundaries can be regarded essentially as additional dislocations producing Taylor hardening. This approach is reasonable but does not take complete account of the interaction of stress fields of closely spaced dislocations. Strengthening by dislocation cell boundaries (LAGB) can be written: 


$$
\Delta \sigma_{\text {cell }}=M \alpha G b \sqrt{\rho_{\text {eff }}}
$$

with $\rho_{\text {eff }}=S_{V} \theta / b=3 \theta / d_{c} b$, and hence

$$
\Delta \sigma_{\text {cell }}=M \alpha G \sqrt{3 \rho b / d_{c}}
$$

$\rho_{\text {eff }}$ is the effective dislocation density of cell walls, $S_{v}$ the boundary area per volume, $\theta$ boundary misorientation, and $d_{c}$ cell size. The reciprocal square root of cell size (i.e. Hall-Petch type dependence), is respected, with Hall-Petch slope $\mathrm{k}_{\text {cell }}$ of $\mathrm{M} \alpha \mathrm{G} \sqrt{ }(3 \theta \mathrm{b})$. For small misorientations, the boundaries are very weak, but for misorientations reaching about $15^{\circ}$ the value of $\mathrm{k}_{\text {cell }}$ is approximately that of standard grain boundaries.

The strength of deformed material should thus be seen as the sum of matrix friction stress $\sigma_{0}$, a term $\Delta \sigma_{\rho}$ taking account of dislocations within the cells, a dislocation cell term $\Delta \sigma_{\text {cell }}$, and a HallPetch term $\Delta \sigma_{\mathrm{HP}}$ taking account of true grain boundaries, as:

$$
\boldsymbol{\sigma}=\boldsymbol{\sigma}_{0}+\Delta \sigma_{\rho}+\Delta \sigma_{\text {cell }}+\Delta \sigma_{\mathrm{HP}}
$$

An analysis of strengthening in heavily rolled $\mathrm{Fe}_{3} \mathrm{Al}{ }^{[82]}$ at increasing strain is shown in figure 8, where dislocation hardening, $\Delta \sigma_{\rho}$, and cell-LAGB hardening, $\Delta \sigma_{\text {cell }}$, add to the initial strength $\left(\sigma_{0}+\right.$ $\left.\Delta \sigma_{\mathrm{HP}}\right)$ to give a good description of observed material strength.

During the initial stages of deformation loose dislocations and dislocation cells lead to rapid hardening, with grain size hardening slowly becoming significant as grain size is reduced and LAGB (cell walls) slowly transition to HAGB (grain boundaries). For nanoscale grain sizes, dislocation and cell hardening will be lost. Neither the simple description of hardness as related to grain size (i.e. $\Delta \mathrm{H} \propto 1 / \sqrt{ } \mathrm{d}$ ) nor as related to dislocation cell size (i.e. $\Delta \mathrm{H} \propto$ $1 / d_{c}$ ) will have full validity, but each will be important within its own corresponding microstructural regime.

\section{SUMMARY}

There now appears to be good understanding of the strengthening occurring as grain size is reduced, and especially the evolution from Hall-Petch behaviour, dependent on consorted dislocation behaviour, to individual dislocation nucleation and glide, and eventually partial dislocation operation.

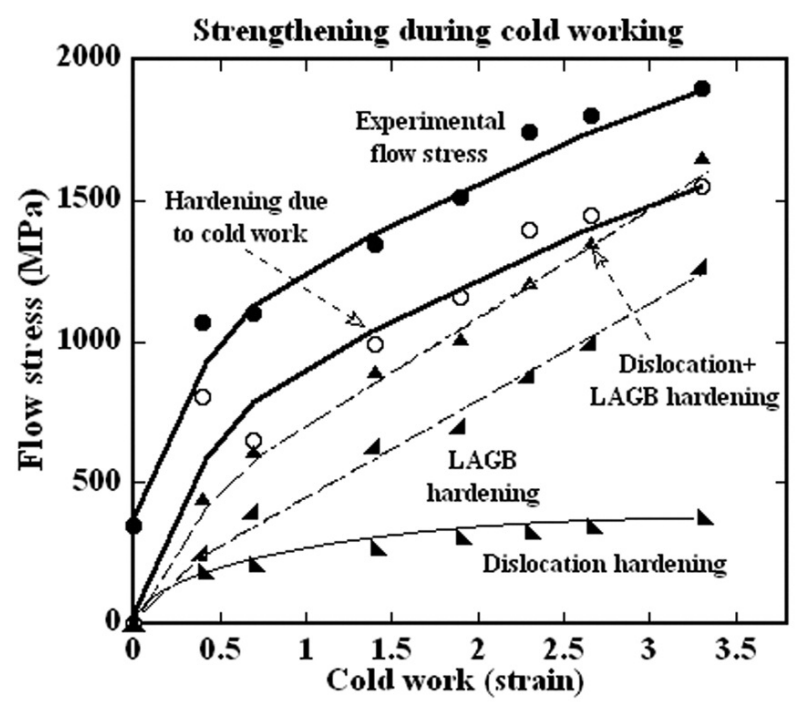

Figure 8. Analysis of hardening during heavy rolling of $\mathrm{Fe}_{3} \mathrm{Al}$. Flow stress is analysed as the sum of an initial, undeformed strength, an increase due to dislocation hardening, and hardening by deformation-induced cell boundaries (LAGB).

Figura 8. Análisis del endurecimiento durante laminado fuerte de $\mathrm{Fe}_{3} \mathrm{Al}$. La resistencia se analiza como la suma de la resistencia inicial del material non-deformado, un incremento debido a las dislocaciones, $y$ un incremento debido a las fronteras de células de dislocaciones (LAGB).

Grain boundaries are both obstacles for dislocations and sources, but are no longer considered important for sliding or diffusion mechanisms. Alloying to produce solid solutions, complex crystal structures or mixed-phase microstructures, offers the possibility to improve stability of the nanostructure at the same time as improving overall mechanical behaviour.

\section{REFERENCES}

[1] D.G. Morris, Strengthening mechanisms in nanocrystalline metals, in Nanostructured Metals and Alloys: Processing, Microstructure and Mechanical properties, Ed. S.H. Wang, Woodhead Publishing Co., Abington, U.K., 2010, pp.

[2] R.J. Asaro and S. Suresh, Acta Mater. 53 (2005) 3.369-3.382.

[3] M. Dao, L. Lu, R.J. Asaro, J.T.M. de Hosson and E. Ma, Acta Mater. 55 (2007) 4041-4065.

[4] M.A. Meyers, A. Mishra and D.J. Benson, Prog. Mater. Sci. 51 (2006) 427-556. 
THE ORIGINS OF STRENGTHENING IN NANOSTRUCTURED METALS AND ALLOYS EL ORIGEN DEL ENDURECIMIENTO DE METALES Y ALEACIONES NANOESTRUCTURADOS

[5] D.G. Morris, Mechanical behaviour of nanostructured materials, Trans. Tech. Publications, Uetikon-Zurich, Switzerland, 1998, pp. 1-86.

[6] J.S.C. Jang and C.C. Koch, Scr. Metall. Mater. 24 (1990) 1.599-1.605.

[7] G.E. Fougere, J.R. Weertman and R.W. Siegel, Nanostruct. Mater. 5 (1995) 127-134.

[8] M. Zhu and H-J. Fecht, Nanostruct. Mater. 6 (1995) 921-924.

[9] J.C. Rawers and G. Korth. Nanostruct. Mater. 7 (1996) 25-45.

[10] T.R. Malow and C.C. Koch, Acta Mater. 46 (1998) 6.459-6.473.

[11] A Munitz, Z. Livne, J.C. Rawers, J.S. Adams and R.J. Fields, Nanostruct. Mater. 11 (1999) 159-177.

[12] D. Jia, K.T. Ramesh and E. Ma, Acta Mater. 51 (2003) 3.495-3.509.

[13] R.K. Guduru, R.O. Scattergood, C.C. Koch, K.L. Murty, S. Guruswamy and M.K. McCarter, Scr. Mater. 54 (2006) 1.879-1.883.

[14] J.D. Embury, A.S. Keh and R.M. Fisher, Trans. Metall. Soc. AIME 236 (1966) 1252-1260.

[15] N. Hansen and B. Ralph, Acta Metall. 30 (1982) 411-417.

[16] G.W. Nieman, J.R. Weertman and R.W. Siegel. Scr. Metall. 23 (1989) 2013-2018.

[17] A.H. Chokshi, A. Rosen, J. Karch and H. Gleiter, Scr. Metall. 23 (1989) 1679-1684.

[18] G.W. Nieman, J.R. Weertman and R.W. Siegel, J. Mater. Res. 6 (1991) 1012-1027.

[19] P.G. Sanders, J.A. Eastman and J.R. Weertman, Acta Mater. 45 (1997) 4019-4025.

[20] G.W. Nieman, J.R. Weertman and R.W. Siegel, Scr. Metall. Mater. 24 (1990) 145-150.

[21] G.E. Fougere, J.R. Weertman and R.W. Siegel, Nanostruct. Mater. 3 (1993) 379-384.

[22] V.Y. Gertsman, M. Hoffman, H. Gleiter and R. Birringer, Acta Metall. Mater. 42 (1994) 3.539-3.544.

[23] Z. Huang, L.Y. Gu and J.R. Weertman, Scr. Mater. 37 (1997) 1071-1075.

[24] C.J. Youngdahl, P.G. Sanders, J.A. Eastman and J.R. Weertman, Scr. Mater. 37 (1997) 809-813.

[25] M. Jain and T. Christman, Acta Metall. Mater. 42 (1994) 1.901-1.911.

[26] M. Hoffman and R. Birringer, Acta Mater. 44 (1996) 2.729-2.736.

[27] T. Volpp, E. Goring, W.M. Kuschke and E Arzt, Nanostruct. Mater. 8 (1997) 855-865.

[28] J.R. Trelewicz and C.A. Schuh, Acta. Mater. 55 (2007) 5.948-5.958.

[29] J.C.M. Li and Y.T. Chou, Metall. Mater. Trans. 1 (1970) 1.145-1.159.

[30] M.F. Ashby, Phil. Mag. 21 (1970) 399-424.
[31] N.A. Fleck, G.M. Muller, M.F. Ashby and J.W. Hutchinson, Acta Metall. Mater. 42 (1994) 475487.

[32] M.A. Meyers and E. Ashworth, Phil. Mag. 46A (1982) 737-759.

[33] D.J. Benson, H-H. Fu and M.A. Meyers, Mater. Sci. Eng. A 319-321 (2001) 854-861.

[34] J.E. Carsley, W.W. Milligan, X.H. Zhu and E.C. Aifantis, Scr. Mater. 36 (1997) 727-732.

[35] Q. Wei, L. Kecskes, T. Jiao, K.T. Hartwig, K.T. Ramesh and E. Ma, Acta Mater. 52 (2004) 1859-1869.

[36] T.G. Nieh and J. Wadsworth. Scr. Metall. Mater. 25 (1991) 955-958.

[37] R.O. Scattergood and C.C. Koch, Scr. Metall. Mater. 27 (1992) 1.195-1.200.

[38] C.C. Koch, Nanostruct. Mater. 2 (1993) 109. 129.

[39] C.S. Pande, R.A. Masumara and R.W. Armstrong, Nanostruct. Mater. 2 (1993) 323. 331.

[40] C. Cheung, F. Djuanda, U. Erb and G. Palumbo, Nanostruct. Mater. 5 (1995) 513-523.

[41] K. Lu, W.D. Wei and J.T. Wang, Scr. Metall. Mater. 24 (1990) 2.319-2.323.

[42] N. Wang, Z. Wang, K.T. Aust and U. Erb, Mater. Sci. Eng. A 237 (1997) 150-158.

[43] C. Xiao, R.A. Mirshams, S.H. Whang and W.M. Yin, Mater. Sci. Eng. A 301 (2001) 35-43.

[44] Y.M. Wang, S. Cheng, Q.M. Wei, E. Ma, T.G. Nieh and A. Hamza, Scr. Mater. 51 (2004) 1.023-1.028.

[45] S.R. Agnew, B.R. Elliot, C.J. Youngdahl, K.J. Hemker and J.R. Weertman, Mater. Sci. Eng. A 285 (2000) 391-396.

[46] F.R.N. Nabarro, Report Conf. Strength Solids, The Physics Society, London, U. K. 1948. pp. 75-80.

[47] C. Herring, J. Appl. Phys. 21 (1950) 437-446.

[48] R.L. Coble, J. Appl. Phys. 34 (1963) 1.6791.681 .

[49] O.A. Ruano and O.D. Sherby, Rev. Phys. Appl. 23 (1988) 625-637.

[50] P.G. Sanders, M. Rittner, E. Kiedaisch, J.R. Weertman, H. Kung and Y.C. Lu, Nanostruct. Mater. 9 (1997) 433-440.

[51] J. Deng, D.L. Wang, Q.P. Kong and J.P. Shui, Scr. Metall. Mater. 32 (1995) 349-352.

[52] Q.P. Kong, B. Cai and M.L. Xiao, Mater. Sci. Eng. A 234-236 (1997) 91-93.

[53] W.M. Yin, S.H. Whang, R. Mirshams and C.H. Xiao, Mater. Sci. Eng. A 301 (2001) 18-22.

[54] B. Cai, Q.P. Kong, L. Lu and K. Lu, Scr. Mater. 41 (1999) 755-759. 
[55] Y.M. Wang, A.V. Hamza and E. Ma, Acta Mater. 54 (2006) 2.715-2.726.

[56] K.S. Kumar, S. Suresh, M.F. Chisholm, J.A. Horton and P. Wang Acta Mater. 51 (2003) 387-405.

[57] M. Chen, E. Ma, K.J. Hemker, H. Sheng, Y. Wang and X. Cheng, Science 300 (2003) 1.275-1.277.

[58] Z. Budrovic, H. van Swygenhoven, P.M. Derlet, S. van Petegem and B. Schmitt, Science 304 (2004) 273-276.

[59] R.J. Asaro, P. Krysl and B. Kad, Phil. Mag. Lett. 83 (2003) 733-743.

[60] J. Schiotz, T. Vegge, F.D. di Tolla and K.W. Jacobsen, Phys. Rev. B 60 (1999) 11.97111.983.

[61] H. van Swygenhoven, A, Caro and D. Farkas, Scr. Mater. 44 (2001) 1.513-1.516.

[62] H. van Swygenhoven, P.M. Derlet and A.G. Froseth, Nature Mater. 3 (2004) 399-403.

[63] J. Schiotz, F.D. di Tolla and K.W. Jacobsen, Nature 391 (1998) 561-563.

[64] J. Schiotz and K.W. Jacobsen, Science 301 (2003) 1.357-1.359.

[65] D.G. Morris and M.A. Morris, Acta Metall. Mater. 39 (1991) 1.763-1.770.

[66] N. Hansen, Scr. Mater. 51 (2004) 801-806.

[67] N. Hansen, Adv. Eng. Mater. 7 (2005) 815-822.

[68] M.A Morris-Muñoz, A. Dodge and D.G. Morris, Nanostruct. Mater. 11 (1999) 873-885.

[69] D.G. Morris, I. Gutierrez-Urrutia and M.A. Muñoz-Morris, Scr. Mater. 57 (2007) 369-372.

[70] M. Krasnowski, A. Witek and T. Kulik, Intermetallics 10 (2002) 371-376.
[71] L. He and E. Ma, Nanostruct. Mater. 7 (1996) 327-339.

[72] R.L. Fleischer, Acta Metall. 14 (1966) 1.8671.868

[73] D.G. Morris, X. Amils, J. Nogues, S. Surinach, M.D. Baro and M.A. Muñoz-Morris, Int. J. Non-Equilib. Proc. 11 (2002) 379-409.

[74] L. Lu, Y.F. Shen, X.H. Chen, L.H. Qian and K. Lu, Science 304 (2004) 422-426.

[75] Y.S. Li, N.R. Tao and K. Lu, Acta Mater. 56 (2008) 230-241.

[76] Y. Zhang, N.R. Tao and K. Lu, Acta Mater. 56 (2008) 2.429-2.440.

[77] E.W. Qin, L. Lu, N.R. Tao, J. Tan and K. Lu, Acta Mater. 57 (2009) 6.215-6.225.

[78] R.Z. Valiev, R.K. Islamgaliev and I.V. Alexandrov, Prog. Mater. Sci. 45 (2000) 103. 189.

[79] R.Z. Valiev and T.G. Langdon, Prog. Mater. Sci. 51 (2006) 881-981.

[80] J. Gubicza, N.Q. Chinh, T.G. Langdon and T. Ungar, Microstructure and strength of metals processed by severe plastic deformation, in Ultrafine Grained Materials IV, Y.T. Zhu, T.G. Langdon, Z, Horita, M.J. Zehetbauer, S.L. Semiatin, T.C. Lowe (Eds.), 2006, , TMS, Warrendale, 2006. pp. 231-236.

[81] R.Z. Valiev, Y.V. Ivanisenko, E.F. Rauch and B. Baudelet, Acta Mater. 44 (1996) 4.705-4.712.

[82] D.G. Morris, I. Gutierrez-Urrutia and M.A. Muñoz-Morris, J. Mater. Sci. 43 (2008) 7.4387.444.

[83] D.R. Leseur, C.K. Syn and O.D. Sherby, Mater. Sci. Eng. A 463 (2007) 54-60. 